\title{
Pacifismo e guerra no pensamento político internacional e a construção de um direito humano e fundamental à paz
}

\author{
Pacifism and War on International Political \\ Thought and the Construction of a Human Right \\ and Fundamental to Peace
}

\author{
Pacifisme et guerre dans la pensée politique \\ internationale et construction d'un droit humain \\ et fondamental à la paix
}

\begin{abstract}
André Luiz Valim Vieira*
SUMÁRIO: I. Introdução. II. Sobre a paz e o pacifismo. III. Sobre a guerra e a paz. IV. O direito humano e fundamental à paz. V. Conclusões. VI. Bibliografia.
\end{abstract}

* Universidade Estadual Paulista, Brasil; ORCID ID: https: / /orcid.org/0000-0003-10526594,andreluizvalimvieira@gmail.com. 
RESUMO: O presente artigo tem por objetivo o estudo do pacifismo e das pesquisas sobre a paz (peace research) em relação à teoria política das relações internacionais que consideram a guerra como objeto de estudo e análise primordial ao longo do pensamento moderno. Utilizando-nos de uma pesquisa histórica e bibliográfica pretendemos identificar o pacifismo e a paz como direito humano e fundamental na ordem internacional e no ordenamento jurídico interno. Nosso objetivo, portanto, consiste em entender o pensamento pacifista no direito internacional e como a paz pode representar a lógica das relações entre as nações no século XXI e como significa um direito fundamental de resguardo na ordem interna e internacional.

Palavras-chave: direitos humanos, guerra, pacifismo, paz.

ABSTRACT: This article aims to study pacifism and peace research in relation to the political theory of international relations that consider war as an object of study and primordial analysis throughout modern thought. Using historical and bibliographical research we intend to identify pacifism and peace as a human and fundamental right in the international order and in the internal legal order. Our goal, therefore, is to understand pacifist thinking in international law and how peace can represent the logic of relations between nations in the 21 st century and how it means a fundamental right of protection in the domestic and international order.

Key words: human rights, war, pacifism, peace.

RÉSUMÉ: Cet article vise à étudier le pacifisme et la recherche sur la paix (peace research) par rapport à la théorie politique des relations internationales qui considèrent la guerre comme un objet d'étude et d'analyse primordiale tout au long de la pensée moderne. En utilisant des recherches historiques et bibliographiques, nous avons l'intention d'identifier le pacifisme et la paix comme un droit humain et fondamental dans l'ordre international et dans l'ordre juridique interne. Notre objectif est donc de comprendre la pensée pacifiste en droit international et comment la paix peut représenter la logique des relations entre les nations au XXIe siècle et comment elle signifie un droit fondamental de protection dans l'ordre national et international. Mots-clés: droits de l'homme, guerre, pacifisme, paix. 


\section{INTRODUÇÃO}

Este trabalho tem por objetivo analisar os temas relativos ao pacifismo e às pesquisas sobre a paz em dicotomia ao fenômeno da guerra nas relações internacionais e como se harmonizam ou se contradizem em consideração como um direito humano e fundamental à paz. Nossa questão se concentra em discorrer se é possível a modificação de um pensamento internacionalista centrado por séculos no fenômeno da guerra para repensar os fundamentos, valores e importância da paz no direito internacional? A paz e as teorias e pesquisas sobre o pacifismo (peace research) concecebem uma autonomia teórico, didática e metodológica a descortinar e suplantar atributo da violência e das guerras nas relações internacionais? Essas nossas hipóteses de debate.

Propomos assim que considerando a autonomia da paz em relação ao pensamento internacionalista clássico a considerá-la somente como ausência de guerra, a paz no direito internacional representaria muito mais um direito humano e fundamental a ser positivado e expresso em normas jurídicas internacionais.

Durante longos séculos a relação entre os temas de paz e a teoria do pacifismo envolveu, necessariamente, perpassar pelo tema da guerra nas teorias políticas e nos tratados e convenções de direito internacional. Para muitos teóricos a paz nada mais significa que a ausência de guerra, todavia, procuraremos demonstrar os escritos sobre a paz e seus diversos conceitos e tipos. Não somente a paz como ausência de guerra, mas sim a paz ativa enquanto possibilidade de construção e manutenção. Com isso, ao finalizar da primeira parte deste artigo, pretendemos aclarar as teorias sobre o pacifismo destacando o pacifismo político e o pacifismo jurídico enquanto doutrinas dos temas da paz.

Para esta primeira tarefa de desenvolvimento dos temas inerentes ao tema da paz e dos pensamentos pacifistas utilizaremos como eixo teórico os trabalhos do pensador político italiano Norberto Bobbio (1909-2004) e do professor brasileiro Rafael Salatini (1980). A dedicação de Bobbio ao estudo dos temas da paz em inúmeras obras compõe todo um cenário de propostas e teorias que procuram sustentar o caminho da paz como uma alternativa aos inúmeros conflitos existentes mundialmente e capazes de ameaças conjunta- 
mente os direitos humanos, a vida das pessoas e a existência das nações perante diversos riscos de conflitos globais e com armas de extermínios totais.

Para a sistematização desse trabalho foi de fundamental importância compreender o alcance das pesquisas acadêmicas para a paz frente à guerra para consolidação dos temas da paz como a melhor opção no cenário internacional para décadas e séculos de conflitos e violências. Dessa forma, para compreendermos o pacifismo e as pesquisas para a paz (peace research) precisamos adentrar sobre o tema da guerra no pensamento político internacional e do direito internacional: o direito à guerra e o direito na guerra: seus limites e condições de existência e manutenção.

Por fim, na última parte deste artigo, analisaremos o tema da paz e da guerra no ordenamento jurídico brasileiro e como, na contemporaneidade do século XXI, tende a se conformar como um direito humano e um direito fundamental a ser positivado e pretegido no âmbito das normas internacionais e das leis internas das nações. Logo, a paz mais do que um atributo de existência condicionada à ausência de guerras representa direito humano e fundamental a ser positivado e protegido pelos normas jurídicas internas e internacionais.

\section{SOBRE A PAZ E O PACIFISMO}

Considerar o século XXI como o período da história — nesses quase dois decênios - como o de maior velocidade, dinamismo e acúmulo de informações se mostra inegável. Enquanto a interação e a comunicação aproximam tecnológica e virtualmente as pessoas; ao mesmo tempo proporcionam o distanciamento vazio e antissinestésico onde o diálogo e a conversa se não realizada por meio de programas, softwares, aplicativos ou outras ferramentas se mostra quase que uma tarefa árdua e difícil. Nesse presente hi-tech ou high tech a comunicação se torna um fim em si mesmo e não um meio para maior aproximação entre pessoas, grupos e nações.

Pensar as relações humanas e as relações internacionais na modernidade consiste ainda em considerar o abrandamento das fronteiras e da ideia máxima de soberania enquanto limites absolutos de atuação do Estado. O fluxo constante de informação e de comunicação, a migração contínua de pessoas e as relações econômicas de ordem global são várias faces da realidade de um mundo atual que diariamente se modifica e se reinventa. As normas jurídicas 
internas e as normas internacionais procuram acompanhar esse avançar em progressão geométrica da sociedade com legislações e preceitos jurídicos que regulam as relações entre indivíduos, entre estes e os Estados e mesmo entre as nações na sociedade internacional.

O direito, portanto, apresenta-se em sua visão clássica como meio de resolução de conflitos e de pacificação por desideratos. As relações internacionais procuram equacionar os temas de interesses e mais relevantes entre as nações. E a ciência política, enquanto uma ciência em constante aperfeiçoamento procura teorizar e criar meios de entendimento sobre a sociedade, o Estado e as normas jurídicas.

Desta feita o fenômeno da normatividade jurídica se encontra de modo perceptível tanto no pretérito como no presente das sociedades e do conjunto coletivo de indivíduos socialmente vinculados pelo contrato social. Dessa forma, as civilizações são caracterizadas pelos ordenamentos de regras nas quais as ações dos homens que a criaram estão contidas. ${ }^{1}$ Poderíamos constatar, assim, que a sucessão de fatos e acontecimentos ao longo da história se apresenta como um complexo de ordenamentos normativos que se sucedem.

Contudo, as normas jurídicas para o filósofo político italiano Norberto Bobbio não passam de uma parte da experiência normativa. Isso porque há no mundo ainda inúmeros preceitos - morais, religiosos, sociais, costumes, etc. — não previstos pelas normas jurídicas, mas nem por isso descaracterizam uma ordem de preceitos cogentes e ordenativos. Todas elas têm em comum o fato de se apresentarem como proposições cuja finalidade é a de influenciar o comportamento de indivíduos e dos grupos, dirigir ações a certos objetivos, tanto do ponto de vista dos sujeitos quanto na ordem do Estado. Constroem-se assim leis e regras de convivência, algumas apresentando preceitos autorizadores e regradores dos negócios e do comportamento, outras trazendo princípios proibitivos e penalizadores, estruturando-se assim o ordenamento jurídico.

Bobbio esclarece essa questão do conflito permanente e da relação da pessoa com seus direitos e proibições quando explana:

Encontrando-se num mundo hostil, tanto em face da natureza quanto em relação a seus semelhantes, segundo a hipótese hobbesiana do homo homini lupus, o homem

1 Bobbio, Norberto, Teoria da norma jurídica, 4a. ed., trad. de Fernando Pavan Baptista e Ariani Bueno Sudatti, Bauru, Edipro, 2008, p. 25. 
buscou reagir a essa dupla hostilidade inventando técnicas de sobrevivência com relação à primeira, e de defesa com relação à segunda. Estas últimas são representadas pelos sistemas de regras que reduzem os impulsos agressivos mediante penas, ou estimulam os impulsos de colaboração e de solidariedade através de prêmios. ${ }^{2}$

Nessa lógica, conjunto de preceitos normativos, de ordem geral e que obrigam a toda a coletividade compõem o ordenamento jurídico de tal comunidade. Na teoria política clássica o Estado enquanto ser potencializador da atividade centralizadora com maior ou menor controle sobre a vida dos indivíduos enquanto em sociedade é o único ser criador das regras de obediência. Logo, não se concebe norma jurídica que não seja emanada do Estado. Exceção feita, contudo, aos defensores da tese do "pluralismo jurídico", ${ }^{3}$ entre outros.

O Estado enquanto ente político que se materializa em uma pessoa jurídica de direito público, interno ou internacional, representa a concentração máxima de poder e direito. O Legislativo enquanto função estatal representante da sociedade e de sua democracia teria a legitimidade para a construção das normas e assim evitar ou diminuir os conflitos. Para Poker, “... a Paz é apresentada simultaneamente como condição, contingência e decorrência de qualquer prática democrática”. ${ }^{4}$ Democracias mais estáveis e historicamente mais consolidadas possuem maiores condições de proporcionar a manutenção da paz aos seus cidadãos. Isso não significa necessariamente a ausência total de conflitos, de modo algum.

Ao tratar do conflito e formulando uma teoria social crítica Axel Honneth, ${ }^{5}$ por exemplo, propõe a construção social da identidade — pessoal e coletiva - como uma gramática do processo de luta, isto é, a luta pelo reconhecimento. Divergindo de Habermas, para ele a base da interação é o conflito, e sua gramática a luta pelo reconhecimento.

2 Bobbio, Norberto, A era dos direitos, trad. de Carlos Nelson Coutinho, São Paulo, Elsevier, 2004, p. 28.

3 Wolkmer, Antônio Carlos, Introdução ao pensamento jurídico crítico, 7a. ed., São Paulo, Saraiva, 2009.

4 Poker, José Geraldo Alberto Bertoncini, "Direitos culturais, universalismo e movimentos sociais: o futuro dos direitos humanos", en Salatini, Rafael (org.), Reflexões sobre a paz, vol. II: Paz e tolerância, Marília, Cultura Acadêmica, 2018, p. 222.

5 Honneth, Axel, Luta por reconhecimento. A gramática moral dos conflitos sociais, 2a. ed., trad. de Luiz Repa, São Paulo, Editora 34, 2009, p. 33. 
Ao Poder Judiciário restaria a tarefa precípua de resolver as lides mediante processos judiciais - consensuais ou contenciosos - mediante o julgamento pelo juiz togado. Juntamente com a capacidade executiva e coercitiva se faria assim a realização da decisão judicial, extinguindo os conflitos de interesses. Alcançando seu intento por meio do Estado-juiz seriam a paz e a pacificação social realizadas. "A vontade popular, expressada por meio dos demais poderes, deve se fazer valer pelo Judiciário, portanto, há limites a serem respeitados, e assim sendo, a sociedade ganha como um todo". ${ }^{6}$

O Estado político e legislativo é a fonte primária das leis e atos ao qual devem todos observar, como preceitos permissivos ou enquanto normas proibitivas sob pena de sofrer a punição provinda do mesmo ente estatal: ao qual muitas vezes se utiliza da violência para o alcance dessa finalidade. Entretanto, imaginando-se o conjunto de pessoas como entidade legitimadora socialmente do poder outorgado ao Estado é de se imaginar que a aparente perfeição e o equilíbrio entre as relações nem sempre se apresentem harmônicas como nas teorias e regras previstas pelo direito.

Para Kant a autonomia individual do indivíduo consista em mera exigência do dever-ser. Na teoria de Hegel, contudo, consistia em elemento da realidade social. A autonomia individual nas sociedades modernas, porém, apresenta-se limitada pela previsão normativa. Sob o argumento de regulação da vida social e resolução de conflitos, ou seja, quando o confronto entre indivíduos se apresenta na esfera das relações de vida em sociedade o Estado procura se apresentar como o ente juiz para resolver o conflito. Quando, porém, apercebe-se um iminente conflito entre as pessoas e o Estado pelo desequilíbrio de avaliações e interesses a desconsideração dos anseios sociais é sempre a saída utilizada desde nas democracias abertas até mesmo nos governos autoritários.

A mais utilizada forma de resistência sempre foi a da violência, do conflito e do confronto, resultando em guerras civis ou ambates armados com inúmeras mortes. Por essa razão, para muitos estudiosos do direito internacional e das relações internacionais ainda, falar em paz representa nada menos que um mero recurso teórico e argumentativo. "A paz ainda é considerada como uma realidade longínqua e aguardada", sendo "os seus propagadores

6 Leão Júnior, Teófilo Marcelo de Ârea e Julias, Lívia Pacheco de Freitas, "A Corte Suprema e o seu papel atual perante a sociedade, judicialização e ativismo judicial adequados", Revista do Instituto de Direito Constitucional e Cidadania, Londrina, vol. 4, núm. 2, dezembro de 2019, p. 206. 
estão mais perto do visionário do que o teórico respeitado", ${ }^{7}$ pois, representa uma realidade ainda inexistente e muito distante.

Ainda assim, tomamos partido na perspectiva jurídica e política de valorização da paz, considerando que, “... .ainda que tenha sido um século marcado por incríveis guerras, o século passado permitiu o avanço tanto da teoria da paz quanto do direito da paz, os quais permanecem vivos até os dias atuais". 8

Norberto Bobbio explica que compreender o conceito e o valor da paz passa, necessariamente, antes por conceituar o que é paz, identificar o valor da paz, para então se entender o conceito e as formas de seu exercício: o pacifismo. Por isso, afirma que, “...quando alguém me pergunta quais são, na minha opinião, os problemas fundamentais do nosso tempo, não tenho qualquer hesitação em responder: o problema dos direitos do homem e o problema da paz". ${ }^{9}$ Pensar, portanto, o pacifismo enquanto teoria e prática envolvem estabelecer suas origens e pressupostos. Dessa forma, conhecendo-se seu surgimento no pensamento político internacional; e, suas condições de exercício e formas de realização prática é possível demonstrar a existência de fundamentos teóricos e bases históricas de aplicação nos dias atuais e vindouros.

Destarte tenha sido do século XX um período em que houve a maior valorização e discussão sobre os direitos humanos há também e diametralmente a época em que a mortandade dos conflitos e guerras alcançaram a marca de milhões de pessoas. O extermínio e as máquinas de combate tomaram proporções e quantidades capazes e suficientes de causar a destruição global. Dessa forma, nunca antes o tema da paz se mostrou tão urgente, sensível e necessário como nos tempos atuais. $\mathrm{O}$ pacifismo e seu exercício são formas legítimas sobre as quais é possível de garantir demais direitos humanos e fundamentais como a vida, a liberdade, a propriedade, a segurança, entre outros.

7 Sala, José Blanes, "A contribuição histórica do direito internacional público para a consecução da paz”, en Salatini, Rafael (org.), Reflexões sobre a paz, Marília, Cultura Acadêmica, 2014, p. 126.

8 Salatini, Rafael, “O tema da paz no século XX”, en Passos, Rodrigo Duarte Fernandes dos e Fuccille, Alexandre (orgs.), Visões do Sul. Crise e transformações do sistema internacional, Marília, Cultura Acadêmica, 2016, vol. 1, p. 35.

9 Bobbio, Norberto, Teoria geral da política: a filosofia política e a lição dos clássicos, trad. de Daniela Beccaccia Versiani, Rio de Janeiro, Campus Editora, 2000, p. 497. 
Contemporaneamente, em âmbito interno das nações quanto para as discussões das relações internacionais o assunto acerca dos direitos humanos representa a pedra filosofal em torno do qual gravitam os temas e problemas. Assim, direitos fundamentais ou direitos humanos são, sem dúvida, tema ainda constante e que muito se mostra ainda a avançar como formas de proteção e como forma de realização e efetivação. Por isso que para Norberto Bobbio:

Além das dificuldades jurídico-políticas, a tutela dos direitos do homem vai de encontro a dificuldades inerentes ao próprio conteúdo desses direitos. Causa espanto que, de modo geral, haja pouca preocupação com esse tipo de dificuldade. Dado que a maior parte desses direitos são agora aceitos pelo senso moral comum, crê-se que o seu exercício seja igualmente simples. Mas, ao contrário, é terrivelmente complicado. Por um lado, o consenso quanto a eles induz a crer que tenham um valor absoluto; por outro, a expressão genérica e única “direitos do homem” faz pensar numa categoria homogênea. Mas, ao contrário, os direitos do homem, em sua maioria, não são absolutos, nem constituem de modo algum uma categoria homogênea. ${ }^{10}$

Esse mesmo diagnóstico é o tema da paz. Imprescindível a teorização e o esforço por meios políticos, jurídicos e sociais de normatização e garantias da paz como primado inescusável da existência de direitos e da própria existência do ser humano.

Ainda hoje a fragilidade dos direitos humanos se mostra não somente na sua desobrigação no âmbito do direito internacional — com a prisão indevida, restrição à liberdade de circulação, julgamentos sem o devido processo legal, não respeito às normas de proteção internacional dos direitos humanos_- senão também nos atos interna corporis dos Estados-nações.

Mesmo aqueles Estados centrados em organização sociais democráticas sob o imperativo da lei, o uso da violência, a injustiça e a brutalidade são muitas vezes ferramentas nas mãos do Estado e dos representantes das chamadas forças públicas: polícia e exército; entidades que sob o atributo de defesa da legalidade e da ordem não medem esforços em se valer da violência como válvula de controle e repressão. Justamente contra toda forma de violência e opressão que afete direitos humanos e ameaça a existência dos

10 Bobbio, Norberto, A era dos..., cit., p. 24 
sujeitos que a retomada do tema da paz e as teorias sobre o pacifismo são um alento e uma esperança: tanto teoricamente quanto metodologicamente.

A palavra paz é um polimorfo. Poder apresentar diversas conotações e sentidos. Tem sua origem do latim pax enquanto estado de tranquilidade; e, de pace, cujo significado é a abstenção de conflito, ausência de belicidade. A paz pode se manifestar enquanto um estado de ser e existir. Consiste na paz interna enquanto consciência e tem por fundamento a moral do sujeito. Seus valores e concepções quando se coadunam com suas atitudes produzem a sensação interna e íntima de bem-estar: muitas vezes entendida como paz de consciência. É a paz subjetiva, interna e individual. A paz, quando estável, é um consentimento geral, um equilíbrio e uma cooperação espontâneos. ${ }^{11}$ A paz interna é aquela que importa ao sujeito e reside em uma situação de existência e harmonia íntima e pessoal.

Quando não há conflitos ou esses se restringem ao campo político e diplomático sem que essas tensões possam promover situações de animosidade ou confrontos que possam resultar em violência. Para Raymond Aron, “...a diplomacia pode ser definida como a arte de convencer sem usar a força, e a estratégia como a arte de vencer de um modo mais direto”. ${ }^{12}$ Mesmo nos limites das relações internacionais a paz pode resultar de medidas diplomáticas surgidas a partir da pactuação de regras e do contrabalanceamento de forças entre os divergentes. É, desse modo, a paz por meio das normas internacionais, dos acordos, dos tratados e das negociações.

Pode, outrossim, surgir a paz como instrumento final de uma guerra anteriormente travada. Em havendo a perpetuação do conflito seu resultado ao findar da guerra traz aos litigantes a sensação da paz. Guerra e paz, portanto, nas relações entre os Estados identificam caminhos possíveis a qualquer nação cuja existência é colocada à prova. Não que a intenção do conflito seja a conquista da paz. Ao contrário, há diversos interesses geopolíticos, territoriais, econômicos, entre outros, a justificar o combate. Todavia, terminandose a guerra com qualquer de seu desfecho traz entre as nações guerreantes a sensação de paz.

Mas, seria mesmo a paz somente alcançável após as guerras e conflitos? Não pode a paz ser um instrumento por si próprio independente da guerra?

11 Bouthoul, Gaston, Viver em paz, trad. de Antonio José Massano, São Paulo, Moraes Editores, 1968, p. 210.

12 Aron, Raymond, Paz e guerra entre as nações, 2a. ed., trad. de Sergio Bath, Brasília, Universidade de Brasília, 1986, p. 73. 
Seria possível a paz ser, portanto, uma ideia inata e propulsora das atividades humanas e da política internacional? Quando se cogita da existência da paz se pensa em um primeiro momento em uma ausência de conflitos ou de guerras. Seria, portanto, a paz não caracterizada por uma razão de existência própria e autônoma, perceptível e reconhecível; mas sim, por uma lacuna, uma ausência um determinado espaço ou período temporal de confrontos. Porém, não é essa a concepção correta como apresentaremos.

$\mathrm{Na}$ filosofia política dos séculos passados os assuntos da guerra foram entendidos como fenômenos positivos. Não há grandes quantitativos de escritos, obras, tratados e manuais sobre a filosofia da paz. Para as relações internacionais e o direito internacional a paz é o período mais ou menos duradouro em que há a ausências de guerras. Essa concepção, contudo, mostrase insuficiente e ultrapassada. Como demonstraremos, a partir de Norberto Bobbio e outros, a paz deve ser pensada não mais como ausência de guerras e sim como um estado de equilíbrio e de satisfação, onde o conflito, o sofrimento e violência são abandonados como ferramentas diárias. A paz, por si própria, tem existência e vida.

Todas as aspirações pacifistas, todas as esperanças de criar um mundo polemófugo, isto é, donde a guerra seria banida, fundam-se implicitamente num postulado: o que se assimila a guerra a um estado patológico, ao equivalente sociológico duma doença, quando a paz seria o estado normal, isto é, a boa saúde. ${ }^{13}$

Falar sobre paz, portanto, ainda é um assunto que causa estranheza no universo da ciência política e das relações internacionais. Esse tema ainda, infelizmente, é muito pouco ou quase nada estudado pelo direito e pelas demais ciências humanas e sociais. As pesquisas sobre a paz ou peace research (PR) se debruçaram sobre a questão da paz e da guerra. Por alguns foi também denominada de polemologia este estudo direcionado às questões da paz. ${ }^{14}$ Permitindo-nos uma licença poética, mesmo nos dias de hoje, a paz ainda é objeto de muitas guerras; ou seja, assusta a muitas pessoas: seja na realidade da vida, seja nas pesquisas acadêmicas e científicas.

As pesquisas sobre a paz conquanto um campo de investigação acadêmica e científica ocorreu nos anos de 1950 e 1960 quando veio a surgir nos

13 Bouthoul, Gaston, op. cit., p. 208.

14 Pontara, Giuliano, "Pesquisa científica sobre a paz", en Bobbio, Norberto et al., Dicionário de política, Brasília, UnB, 1992, vol. 2, p. 916. 
Estados Unidos, na Universidade de Michigan, o Centrer for Research on Conflict Resolution (Centro de Pesquisas para Resolução de Conflitos) que originou o periódico Journal of Conflict Resolution. Outro importante núcleo de pesquisas sobre a paz teve a iniciativa de Johan Galtung com a criação do Internacional Peace Research Institute of Oslo (Instituto Internacional de Pesquisas de Oslo para a Paz) e sua publicação, até hoje referência na área, Journal of Peace Research.

Ainda no tema dos centros universitários criados para a peace research poderíamos citar ainda o Peace Research:The Canadian Journal of Peace and Conflicts Studies, nascido em 1969, e hoje localizado em seu centro de pesquisas sobre a paz da Universidade de Winnipeg. E não podemos deixar de fazer referência ao Albert Einstein Institute, fundado por Gene Sharp, em 1983, como uma organização destinada ao avanço dos estudos e usos das estratégias e ações não violentas em conflito.

Conforme Vanessa Matijascic: “...os professores e pesquisadores para a paz formados nesse ambiente universitário são conhecidos pela perspectiva crítica das atuais estruturas de poder, a dinâmica da política internacional e da conjuntura da segurança internacional". ${ }^{15}$ Com Johan Galtung a peace research ganha novos modelos de pesquisa sobe a paz. Passa a considerar a violência como uma inimiga a ser evitada para ao alcance da paz.

A paz até então entidade como ausência de guerra: paz negative, passa a ser pensada como paz positive (positive peace): a paz pela paz. A paz como proposta de pesquisa e como esforço conjunto e contínuo para sua realização e manutenção. Johan Galtung convoca os pensadores do mundo a buscar soluções e alternativas que promovam a redução da violência e tenham por objetivo a promoção da paz.

Nas palavras de Bouthoul admitir a existência de uma polemologia, mesmo imperfeita e ainda hesitante constitui, no entanto, uma esperança gigantesca. ${ }^{16}$ As pesquisas sobre a paz ganham então estímulo e mais impulso e fôlego no século XXI. A sociedade internacional, de um modo geral, não mais se coaduna e nem aceita os conflitos e as guerras como soluções para resolução de problemas. A paz precisa ser estudada, entendida, praticada. Guerras e conflitos bélicos ou armados apenas trazem sofrimento, violên-

15 Matijascic, Vanessa Braga, "Pesquisas para a paz e o ativismo da cultura da paz", en Salatini, Rafael e Dias, Laércio Fidelis (orgs.), Reflexões sobre a paz, vol. II: Paz e tolerância, São Paulo, Cultura Acadêmica, 2018, p. 38.

16 Bouthoul, Gaston, op. cit., p. 224. 
cia e prejuízos; sejam estes sociais, econômicos, humanos, ambientais. Os estudos direcionados ao entendimento da paz se propõem a ser a melhor alternativa contra toda e qualquer guerra ou conflito.

Se durante muitos decênios a polemologia esteve adstrita ao estudo da guerra e sua ocorrência a partir de fenômenos sociais, psicológicos e políticos; em tempos modernos ou pós-modernos os esforços que antes se dedicavam a teorizar e criar argumentos e hipóteses a justificar o fenômeno da guerra devem agora fazê-lo em prol dos estudos sobre a paz. A polemologia representa “...o estímulo cientificamente mais válido para dessacralizar o fenômeno da guerra desmascarando-o sob os disfarces ideológicos e políticos geralmente invocados". ${ }^{17}$ A polemologia permite dessacralizar e despoliticizar as tensões, considerar estas como as resultantes dos desequilíbrios sociológicos, e não como fatalidades, predestinações ou simples caprichos. ${ }^{18}$

A guerra com isso deixa de ser um fenômeno sagrado, como historicamente têm se afirmado. Abandona-se a fala da guerra como vontade divina ou sob imperativo do governante em prol do povo e de seu bem-estar para melhor compreender o pacifismo e paz como via alternativa e mais segura.

Para Rafael Salatini, ${ }^{19}$ podemos dividir o pensamento pacifista moderno, aquele do século XVI ao XIX, em três grandes correntes: (a) a teoria do irenismo cristão; (b) a teoria da cidade pacífica ideal; e (c) a teoria do federalismo internacional. A primeira busca a paz com fundamento nos ensinamentos cristãos e religiosos. A segunda a que considera que uma cidade perfeita não reside motivos para atacar outra. E, por terceira, a teoria de que a paz nasce de um acordo internacional entre as nações. Essa terceira via ancorada nas ideias de paz perpétua de autores como Saint-Pierre e Kant.

A primeira corrente tem por base a teoria da paz em pensamentos cristãos e religiosos. A paz seria uma consequência das tarefas de unificação da religião e aproximação dos homens entre si. São representantes desse primeiro movimento, nos séculos XV e XVI, as obras de Nicolau de Cusa (De pace et concordantia fidei, de 1453) e Erasmo de Rotterdã (Guerra, de 1515, e Querela da paz, de 1517).

17 Fotia, Mauro, "Polemologia, psicanálise e ciência política”, Revista de Ciência Política, Rio de Janeiro, vol. 2, setembro-dezembro de 1980, p. 123.

18 Bouthoul, Gaston, op. cit., p. 225.

19 Salatini, Rafael, “O tema da paz perpétua”, Brazilian Journal of International Relations, Marília, vol. 2, núm. 1, janeiro-abril de 2013. 
A paz da fé, de Nicolau de Cusa, denominação de Nicolau Krebs, acrescido do seu local de nascimento (Kues). A construção de sua obra, no século $\mathrm{XV}$, envolve uma narrativa religiosa de caráter teatral. Por fim, entende que o conhecimento da verdade a todas as nações deveria chegar para em comunhão, a uma só fé com o intuito de edificar uma paz perpétua entre os homens, como representação da paz do criador. ${ }^{20}$ As guerras movidas e que resultaram na queda de Constantinopla é o marco para a construção dessa narrativa de diálogo entre a representação divina e a representação dos homens de diversas nações.

Seguidamente, temos a teoria da cidade pacífica ideal, em que o tema da paz passa a ser uma questão da política e da forma pela qual as instituições devem buscá-la. São representantes desse período Thomas More (Utopia, de 1516), Émeric Cruc (Novo Cirineu, de 1623) e William Penn (Ensaio para chegar à paz presente e futura da Europa, de 1693).

$\mathrm{Na}$ terceira corrente de pensamento sobre a paz, encontramos o tema da paz como "federalismo internacional", no qual a paz somente pode nascer de um acordo internacional de defesa mútua entre as nações. ${ }^{21}$ Dessa filosofia, centrada nos séculos XVII e XVIII, encontramos as obras de Hugo Grócio (Direito de guerra e da paz, de 1625), Saint-Pierre (Projeto para tornar perpétua a paz na Europa, de 1713), Jeremy Bentham (Um plano para uma paz universal e perpétua, de 1789) e, finalmente, a obra mais conhecida, Kant (Sobre a paz perpétua, de 1795-1796).

Desse terceiro período destaca-se a obra de Hugo Grócio; e os escritos do Abbé de Saint-Pierre, nome de Charles Irénée Castel de Saint-Pierre, ${ }^{22}$ e sua grande e vastíssima obra —originalmente publicada em três volumessobre as vantagens de adesão a um sistema de paz perpétua ou inalterável contra um sistema de guerra na Europa.

Falar sobre a paz ainda que não se mostre impossível, mesmo nos escritos anteriores do século XV ao século XIX, apresenta-se como uma tarefa hercúlea para desconstrução paradigmática de seu conceito apenas como a ausência de guerra. Exemplo disso encontramos em Raymond Aron ao considerar a paz como “... a suspensão, mais ou menos durável, das modalidades vio-

20 Cusa, Nicolau de, A paz da fé, trad. de João Maria André, Coimbra, Minerva Coimbra, 2002, p. 82.

21 Salatini, Rafael, “O tema da paz perpétua”, op. cit., p. 142.

22 Saint-Pierre, Abbé de, Projeto para tornar a paz perpétua na Europa, trad. de Sergio Duarte, Brasília, Editora UnB, 2003, p. 101. 
lentas da rivalidade entre os Estados". ${ }^{23}$ A paz, assim, durante grande parte do pensamento político internacionalista, têm se sustentado enquanto uma definição negativa. Por essa razão que para se compreender as teorias sobre a paz é imperioso passar pelo tema da guerra. Nossa hipótese justamente se harmoniza com o entendimento de que a paz é a antinomia da guerra; contudo, não representa unicamente a ausência de guerra. Significa, mais que tudo, em uma concepção positiva e ativa de representação e existência.

\section{SOBRE A GUERRA E A PAZ}

O conceito de paz está intimamente ligado ao conceito de guerra. ${ }^{24}$ São termos em permanente confronto e contraposição. São antítese um do outro. Onde existe um se mostra impossível a existência concomitante do outro. A guerra é a situação ou estado onde o conflito e a violência se apresentam como métodos rotineiros e necessários. A paz, outrossim, seria então a ausência de conflitos ou de guerras. Durante séculos esse foi o pensamento dominante na ciência política e nas relações internacionais. Por essa razão que ainda muitos afirmam que a história escrita do mundo é uma história de guerras. ${ }^{25}$

Norberto Bobbio quando se depara com o tema guerra versus paz parte do pressuposto de que, para se entender o estado de paz, é preciso primeiro compreender o estado de guerra. Por isso, afirma que “...pode-se dizer que existe um estado de guerra quando dois ou mais grupos políticos encontram-se entre si um uma relação de conflito cuja solução é confiada ao uso da força”. ${ }^{26}$

O professor de Turim em seus escritos sobre a paz é capaz de trabalhar os conceitos de guerra e paz realizando a inversão do adágio romano se vis pacis, para bellum para a máxima de se vis pacis, para pacis. ${ }^{27}$ Se a literatura das ciências políticas e internacionalistas antes consideravam que o caminho para

23 Aron, Raymond, op. cit., p. 220.

24 Bobbio, Norberto, Teoria geral da política..., cit., p. 509.

25 Keegan, John, Uma história da guerra, trad. de Pedro Maia Soares, São Paulo, Companhia das Letras, 1998, p. 492.

26 Bobbio, Norberto, Teoria geral da política..., cit., p. 513.

27 Salatini, Rafael, "Bobbio, a paz e os direitos do homem”, Revista Direito GV SP, janeirojunho de 2011, p. 334. 
a paz era guerra, Bobbio avança no imperativo moral de que o caminho para a paz é a própria paz.

Bobbio então expressa seu entendimento da guerra como um conflito entre grupos políticos independentes cuja solução é confiada à violência organizada. Esses grupos em conflito detentores do poder jurídico se utilizam do monopólio da força, seja física ou institucional, para submeter seus confrontantes à sua dominação. Por esse ínterim que, conclui que "... a guerra, enquanto solução de um conflito entre grupos políticos através do uso da força, é um dos modos de solucionar um conflito, à qual geralmente se recorre quando os modos pacíficos não surtiram efeito". ${ }^{28}$

Considerar esta a ordem natural das relações, todavia, reduz o tema da paz unicamente como o momento em que a força, a violência e a guerra enquanto ferramentas de poder e de dominação não são utilizadas. De tal forma que o tema paz não importaria em existência autônoma e relevante; senão como períodos determinados e esporádicos sem as guerras. Essa visão predominante nas teorias políticas internacionais encontra resistência no pensamento do jusfilósofo italiano.

Para Bobbio a guerra é a expressão conclamada da irracionalidade anárquica em que se encontram as relações entre Estados soberanos. O grande perigo presente no equilíbrio terrorístico entre as grandes potências militares marca a fragilidade das teorias tradicionais do equilíbrio internacional. E mostra, ao mesmo tempo, a impotência das instituições internacionais. ${ }^{29}$

A cogitação da guerra como o estado natural da sociedade em conflito, considerando o ser humano no estado de permanente de confrontação com seu semelhante, encontra guarida nas ideais e nos escritos de Thomas Hobbes. Ou, em outra medida, o pensamento de Rousseau e da inocência do ser vivente, segundo o qual a guerra é a escolha dos poderes constituídos e cabe ao ser social o enfretamento com seu semelhante com imposição do Estado soberano. Nesses termos, pode-se afirmar sobre o pensamento internacionalista rousseauneano:

28 Bobbio, Norberto, Teoria geral da política..., cit., p. 514.

29 Zolo, Danilo, "Luzes e sombras do pacifismo jurídico de Norberto Bobbio", en Tosi, Giuseppe (org.), Norberto Bobbio: democracia, direitos humanos, guerra e paz, João Pessoa, Editora da UFPB, 2013, p. 323. 
Como o estado de natureza no qual nascem os indivíduos é distinto daquele em que surge o sistema internacional, o primeiro sendo pacífico e o segundo, belicoso, não se pode considerar como guerra a relação de inimizade entre os indivíduos, o que é contra sua natureza, mas apenas aquela entre Estados, onde a mesma é natural (e, portanto, legítima), sendo que os homens somente se tornam soldados depois de se tornarem cidadãos — duas dimensões que não se confundem em absoluto— do que segue a distinção corriqueira até os dias atuais entre civis e militares (existem, inclusive, os alvos civis, como hospitais e escolas, e os alvos militares, como quartéis e bases). Dessa forma, para Rousseau, apenas os Estados podem fazer guerra entre si, não o podendo nem os indivíduos entre si (o que não é senão uma guerra civil, que Hobbes erroneamente confunde com a guerra propriamente dita) nem os Estados contra os indivíduos (o que pode ser chamado de terrorismo de Estado) nem os indivíduos contra o Estado (o que deve ser chamado, segundo cada caso, de conjuração, sublevação, revolta, revolução, etc.). Isso porque a guerra consiste numa relação pública entre dois corpos públicos, que demanda, antes de qualquer coisa, uma declaração, seja explícita ou implícita, para se iniciar, assim como um documento de rendição para se findar, sem os quais as agressões, assim como o seu fim, não podem ser consideradas senão como agressões privadas e, enquanto tais, inferiores à instituição da guerra enquanto fenômeno público (como são os fenômenos que envolvem, via de regra, o Estado), que não gera direitos privados (como são tipicamente os direitos individuais). ${ }^{30}$

O direito internacional e os escritos de ciência política, quando tratam do tema da guerra, utilizam as expressões jus ad bellum (direito da guerra) e jus in bello (direito na guerra). O primeiro — jus ad bellum — fala do direito de um Estado político independente de se utilizar da força quando assim se mostra necessário. Especialmente em resposta a agressões ou como última medida para quaisquer outros meios diplomáticos de ameaças. O jus in bello, por outro lado, visa a regular as normas e limites quanto à utilização do uso da força. Dessa forma, mesmo perante um conflito bélico, são necessários estabelecer regras para o uso da força: onde, por qual meios, contra quem, àqueles que devem ser protegidos e formas de tratamento de prisioneiros.

Infelizmente, o estado de guerra não desconsidera apenas o direito à vida, mas suspende a proteção de outros direitos fundamentais do homem, tais como o direito de

30 Salatini, Rafael, "Rousseau e as relações internacionais”, Pacifismo e cooperação nas relações internacionais: teoria e prática, Dourados, UFGD Editora, 2013, p. 30. 
liberdade. Com isso quero dizer que o estado de guerra pode ser justificação válida para induzir um governo, mesmo que não-autocrático, a comportar-se de modo autocrático. Continua válido o velho ditado: inter arma silente legis. E de qualquer modo continua válido também o princípio de que a necessidade não tem lei, e a guerra aciona um estado de necessidade que, como tal, sendo lei em si mesma está acima de qualquer lei (natura ou positiva). ${ }^{31}$

Em tempos em que as armas de guerra não são mais capazes de distinguir os soldados em campo de batalha e os civis carentes de proteção, em que os instrumentais de destruição são capazes de dizimar uma quantidade inumerável de sujeitos alcançando o inimigo e ao mesmo tempo àqueles que nada têm a ver com o conflito, a discernibilidade da guerra, enquanto justa ou injusta, põe em dúvida sua capacidade de proteção aos direitos fundamentais e de imposição de limites a si mesma.

Toda e qualquer guerra, desde os tempos medievais até as atuais guerras modernas e tecnológicas em que drones ou aviões e caças são utilizados para assassinar inimigos e intimidar nações não é possível se eliminar baixas que não sejam militares. Toda guerra traz consigo a atingimento de alvos civis, casas, escolas, hospitais, campos de refugiados e diversos outros locais que não participam do conflito, porém, sofrem a consequência das loucuras de seus governantes e dirigentes políticos.

Nesse sentido o pensamento do professor de ciência política da Universidade de Roma quando critica a guerra, fazendo referência ao seu significado simbólico e psicanalítico:

Guerra como orgia da dissipação, na qual os velhos sepultam os jovens, e os jovens se sacrificam para fazerem sobreviver as ilusões dos velhos. Orgia sustentada pelo esforço prolífico das mães, que concebem, criam os filhos com desvelo, incutindolhes respeito e dedicação a fim de que sejam mais corajosos para receber e infligir martírio. Desde as preleções escolares, às paradas, aos rituais nos locais das recordações, tudo parece ser predisposto a permitir que cada geração viva paradoxalmente como necessidade ética normal a máxima e insensata criminalidade da guerra.Violência institucionalizada que encontra a sua sanção legitimadora naquelas leis morais que deveriam condená-la. ${ }^{32}$

31 Bobbio, Norberto, Teoria geral da política..., cit., p. 449.

32 Fotia, Mauro, op. cit., p. 123. 
A guerra enquanto fenômeno político e social longínquo na existência humana acaba por se renovar constantemente, desde a definição de Hugo Grócio, segundo quem a guerra “...é o estado de indivíduos, considerados como tais, que resolvem suas controvérsias pela força". ${ }^{33}$

A própria guerra ganha novos adjetivos e novas formas de intimidação e confrontação. A guerra surge como um medo, um temor, uma ameaça cuja realidade fria pode se tornar quente e efetiva a qualquer tempo, trazendo consigo a ausência de limites e regras. "Não é nem mesmo necessário o estado de guerra efetivo: é suficiente o estado de guerra potencial, a guerra fria, para fazer prevalecer, em determinados casos, a razão de Estado sobre a razão humana, que desejaria ver garantidos os direitos do homem". ${ }^{34}$

Segundo o conceito de Carl von Clausewitz, a guerra nada mais é que um duelo em uma escala mais vasta, ou, em seus exatos termos, “.... guerra é pois um ato de violência destinado a forçar o adversário a submeter-se à nossa vontade”. ${ }^{35} \mathrm{O}$ adversário, portanto, é sempre o outro e pode ser qualquer um dos outros e demais.

$\mathrm{Na}$ ciência da guerra, os avanços e descobertas servem como elemento de vantagem perante o inimigo. Na economia da guerra, as teorias e temas se submetem à vontade estatal em que o conflito bélico se torna a principal atividade e mais relevante objetivo do governante. Sendo que a questão da guerra nas relações internacionais e na ciência política transforma esse fenômeno histórico e social de conflito em uma ciência. O esforço da ciência da guerra é para causar morte e sofrimento da forma mais devastadora e metódica possível. ${ }^{36}$

O direito internacional público trata do assunto da guerra quando se propõe a ser um instrumental para estudos e entendimentos ao direito e às relações internacionais. De um modo amplamente aceito na atualidade, a guerra é um ato de violência atualmente inadmitido em direito internacional público. Para Mazzuoli, a guerra representaria, pois,

33 Grotius, Hugo, O direito da guerra e da paz, 2a. ed., trad. de Ciro Mioranza, Ijuí, Unijuí, 2005, vol. I, p. 72.

34 Idem.

35 Clausewitz, Carl von, Da guerra, trad. de Maria Teresa Ramos, São Paulo, Martins Fontes, 1996, p. 7.

36 Bonanate, Luigi, A guerra, trad. de Maria Tereza Buonafina e Afonso Teixeira Filho, São Paulo, Estação Liberdade, 2001, p. 22. 
...todo conflito armado entre dois ou mais Estados, durante um certo período de tempo e sob a direção dos seus respectivos governos, com a finalidade de forçar um dos adversários a satisfazer a(s) vontade(s) do(s) outro(s). Ela normalmente se inicia com uma declaração formal de guerra e termina com a conclusão de um Tratado de Paz, ou outro ato capaz de pôr termo às hostilidades e findá-la por completo. ${ }^{37}$

Ainda sim este fenômeno pode ser considerando sob diversas vertentes. Uma guerra além da motivação jurídica pode ser estabelecida a partir de propósitos políticos, econômicos, intervencionistas, entre outros.

O direito de guerra ou o direito aplicável na guerra (jus in bello) representava o conjunto de normas aplicáveis durante as guerras. Diferenciava-se do jus ad bellum como direito à guerra. Uma opção lícita para resolver conflitos entre Estados, ${ }^{38}$ na opinião do ex-ministro de Relações Exteriores do Brasil.

Para Clausewitz, o filósofo da guerra, qualquer guerra será considerada como um ato político, ou, novamente em suas palavras, “... a guerra não é somente um ato político, mas um verdadeiro instrumento político, uma continuação das relações políticas uma realização destas por outros meios" ${ }^{39}$ Pois, até então para os teóricos das relações internacionais:

A guerra foi o meio pelo qual obteve-se consenso no passado. A paz decide questões que a guerra definiu, joeirou e apresentou de uma forma pronta para resolução. As grandes conferências de paz que encerraram guerras momentosas serviram de convenções constitucionais para a sociedade de Estados, convocadas para responder a questões postas à prova pela violência do Estado. ${ }^{40}$

A guerra seria, segundo esses pensadores e teorizadores, o caminho para a paz. O fim da guerra é a paz, à qual todos devem aspirar. ${ }^{41}$ Sob esse prisma a paz somente seria alcançável por meio da guerra. O objetivo de toda guerra seria então a pactuação e perpetuação da paz. A guerra seria o ins-

37 Mazzuoli, Valerio de Oliveira, Curso de direito internacional público, 9a. ed., São Paulo, Revista dos Tribunais, 2015, p. 1189.

38 Rezek, Francisco, Direito internacional público. Curso elementar, 15a. ed., São Paulo, Saraiva, 2014, p. 421.

39 Clausewitz, Carl von, op. cit., p. 27.

40 Bobbitt, Philip, A guerra e a paz na história moderna. O impacto dos grandes conflitos e da política na formação das nações, trad. de Cristiana de Assis Serra, São Paulo, Campus, 2003, p. 746.

${ }_{41}$ Gentili, Alberico, O direito de guerra, trad. de Ciro Mioranza, Ijuí, Unijuí, 2006, p. 435. 
trumento pelo qual se alcançaria a paz. Mas seria isso verdade? O único caminho possível? Ultrapassar o pensamento pacifista inicial que considerava e aceitava a fala da guerra como único meio é necessário para a construção de um pensamento genuinamente pacifista. A paz não é apenas o fim, senão o meio para as contendas e conflitos.

Embora a guerra ainda hoje tenha seus adeptos e defensores nas universidades e principalmente nos meios militares e na economia da guerra como aqueles que dizem que a longo prazo a guerra tem tornado o mundo mais seguro e mais rico_- ${ }^{42}$ o objetivo de propor o pacifismo como alternativa à guerra não tem por objetivo julgar os fatos pretéritos senão propor que eventuais conflitos, presentes e futuros, não comportam mais medidas que tenham sustentação nos argumentos da legítima defesa ou mesmo de contramedidas, isto é, represálias ou ataques em respostas a uma primeira agressão internacional.

Eduardo Mei nos diz ainda que, após a Guerra Fria, temos o surgimento de "novas guerras". ${ }^{43}$ São os conflitos que não tem por objetivo a paz, ou seja, a paz negociada ou a paz imposta. Não se procura alcançar a paz ou uma ordem política qualquer. Tais guerras não seriam nem mesmo protagonizadas por Estados: como o terrorismo e as ações de grupos armados.

Alguns teóricos argumentam ainda da guerra como uma necessidade e uma saída para situações em que não se encontra outras soluções. Aquilo que se denomina como teoria da guerra justa. Surge, então, como uma proposta filosófica com argumentos que procuram justificar justas causas, condições necessárias em que se pode se valer da declaração de guerra e do conflito armado como pretexto e justificadora de determinados fins.

A teoria da guerra justa defende a existência de cinco causas justas para a legitimação de uma ação armada. Estas são: a autodefesa da agressão prévia, guerra indireta como autodefesa, guerra punitiva por agressões não reparadas na época, guerra preventiva a um ataque iminente, e guerra por razões humanitárias. ${ }^{44}$ Os defensores da teoria da guerra justa argumentam que o

42 Morris, Ian, Guerra. O horror da guerra e seu legado para a humanidade, trad. de Luis Reyes Gil, São Paulo, LeYa, 2015, p. 7.

43 Mei, Eduardo, "Estado, guerra e violência: as novas guerras e suas implicações para a teoria clausewitziana da guerra”, en Mei, Eduardo e Saint-Pierre, Héctor Luis (orgs.), Paz e guerra. Defesa e segurança entre as nações, São Paulo, Editora Unesp, 2013, pp. 44 e 45.

44 Díaz i Anabitarte, Aitor, "Hacia una sistematización del pacifismo político", Revista Española de Ciencia Política, Madrid, núm. 31, 2013, p. 179. 
conflito nem sempre pode ser evitado, posto que, em algumas circunstâncias a guerra será uma necessidade em proteção a um mal maior. Como afirma Keegan, ${ }^{45}$ a política deve continuar; a guerra, não.

Otfried Höffe citado por Poker nos diz que “... a Paz é a tendência predominante em todas as situações de convivência humana, seja no âmbito da ordem externa ou da ordem interna, por mais que as evidências provenientes da vida prática indiquem o contrário" ${ }^{46} \mathrm{~A}$ paz, portanto, é o caminho presente e futuro - em nível nacional ou na relação entre os Estados soberanos - para a convivência entre as pessoas. A guerra impõe sofrimento, morte, destruição, prejuízos de toda monta. Se o conflito é inerente à própria existência humana e da dinâmica da convivência social, não sendo possível sua eliminação total, melhor saída é a resolução de contendas por meio da paz.

A paz serve a contento como ferramenta interna e externa. Da mesma forma em que constitui norma jurídica de direito humano já reconhecida como veremos.

\section{O DIREITO HUMANO E FUNDAMENTAL À PAZ}

Para Bobbio, pensar na paz envolve pensar na guerra; afinal, comporiam ambos um termo par. Tanto é assim que, segundo o autor, na literatura sobre o tema da guerra e da paz, encontram-se infinitas definições guerra, enquanto seria a paz a cessão ou conclusão ou ausência de guerra. ${ }^{47}$

Pensar a paz como sendo a ausência de guerra ou de conflitos importaria em um conceito negativo, ou seja, “....um estado nas relações internacionais antitético ao estado de guerra”. ${ }^{48}$ Porém, nas ideias do filósofo italiano, há ainda o sentido positivo e específico de paz, qual seja, o de peace research.

Insatisfeito com a definição puramente negativa de paz, sobrepõe a ela uma definição positiva, que deriva de entender extensivamente "paz" como negação não

45 Keegan, John, op. cit., p. 499.

46 Poker, José Geraldo Alberto Bertoncini, "Direitos culturais, universalismo e movimentos...”, op. cit., p. 219.

47 Bobbio, Norberto, Teoria geral da política..., cit., p. 510.

48 Ibidem, p. 516. 
tanto de guerra quanto de violência. Diferenciando portanto duas formas de violência, a violência pessoal, na qual está incluída a forma específica de violência que é a guerra, e a violência estrutural ou institucional, distingue duas formas de paz, a negativa, que consiste na ausência de violência pessoal, e a positivam que consiste na ausência de violência estrutural. Enquanto ausência de violência estrutural —que é a violência que as instituições de domínio exercem sobre os sujeitos ao domínio, e em cujo conceito se incluem a injustiça social, a desigualdade entre ricos e pobres, entre poderosos e não-poderosos, a exploração capitalista, o imperialismo, o despotismo, etc. - a paz positiva é aquela que pode ser instaurada somente através de uma radical mudança social e que, pelo menos, deve avançar lado a lado com a promoção da justiça social, com o desenvolvimento político e econômico dos países subdesenvolvidos, com a eliminação das desigualdades. ${ }^{49}$

Pensar sobre a paz pode parecer, inclusive refletindo sobre o seu conceito, como o estado ou situação de ausência de conflito. Ocorre que para se pensar um estado de paz é algo contraditório com a própria natureza humana e seu estado de conflito. Pois, “... existe situação de conflito sempre que as necessidades ou os interesses de um indivíduo ou de um grupo não podem ser satisfeitos senão com dano de outro indivíduo ou grupo...".50 Ao analisar a questão da paz e sua antinomia com a teoria hobbesiana que pressupõe o conflito como algo permanente e inerente, Rafael Salatini nos chama a atenção:

Bobbio analisou, concentrada e sistematicamente, os seguintes problemas relacionados ao tema da paz: (a) o problema da definição, (b) o problema da classificação, (c) o problema da valoração, (d) o problema do estado intermediário, (e) o problema do pacifismo, e (f) o problema do federalismo. Pode-se mesmo dizer que, nesses textos, Bobbio tentou apresentar (embora não expresse com esses termos) uma teoria geral da paz. ${ }^{51}$

Norberto Bobbio nos diz que a paz é um dos objetivos possíveis. Mas não o único. Esclarece ele que: "A paz é um fim altamente desejável para o homem, mas não é dito que seja, em sentido absoluto, o último objetivo. É o último

49 Ibidem, p. 517.

50 Bobbio, Norberto et al., Dicionário de política, Brasília, UnB, 1992, vol. 2, pp. 911 e 912.

51 Salatini, Rafael, "Introdução aos escritos sobre a paz de Norberto Bobbio", Revista Videre, Dourados, vol. 10, núm. 18, 2017, p. 56. 
objetivo apenas para quem considera que a vida seja o bem supremo". ${ }^{52} \mathrm{~A}$ paz embora possa se apresentar como o objetivo final que deve ser alcançado ela não significa a negação de outros objetivos e metas da convivência social.

"A paz não é o fim por excelência, mas um dos fins possíveis. O meu comportamento diante dos que sustentam a paz depende do lugar que atribuo à paz na minha hierarquia de valores". ${ }^{53}$ A paz não se mostra então como atributo negativo como a mera ausência de guerra. Seria, ao contrário, a paz um elemento de direito humano e fundamental imperativo e imprescindível à toda existência com dignidade — atendendo ao comando constitucional_ bem como um pré-requisito para o exercício dos demais direitos individuais, sociais e coletivos.

Poker menciona que os direitos humanos possuem uma condição histórica e por essa razão não podem se restringir somente à Declaração de 1948 . Sendo assim “... devem ser tratados como uma peça normativa que continua em processo de desenvolvimento, ao mesmo tempo em que experimenta a efetivação, como qualquer peça do direito racional". ${ }^{54}$

O uso indiscriminado do termo "direitos humanos" para tratar de direitos conseguidos a partir das lutas históricas no decorrer dos tempos nem sempre encontra ressonância na significação exata da expressão com sua essencialidade. Apresenta-se como um termo genérico e plástico, facilmente maleável para que possa se encaixar a uma gama de direitos referentes ao aspecto da vida, da liberdade, e dos direitos de convivência e de sociedade, como uma fórmula pronta, porém libertina onde se podem incluir vários tipos de pretensões sem uma identificação clara e precisa de seu conteúdo. Todavia, por sua significação heterogênea em grande parte suscitada por esse uso indiscriminado; utilizada tanto no âmbito da teoria quanto na práxis, a expressão "direitos humanos" tem se apresentado como um paradigma de equivocidade. ${ }^{55}$

Segundo o professor espanhol Peces-Barba Martínez, ${ }^{56}$ a expressão "direitos fundamentais" é mais adequada para se referir à categoria de direitos

52 Bobbio, Norberto, "Paz e propaganda de paz", Brazilian Journal of International Relations, Marília, vol. 4, núm. 1, janeiro-abril de 2015, p. 137.

53 Idem.

54 Poker, José Geraldo Alberto Bertoncini, "Direitos culturais, universalismo e movimentos...”, op. cit., p. 217.

55 Pérez Luño, Antonio Henrique, Derechos humanos, Estado de derecho y Constitución, 9a. ed., Madrid, Tecnos, 2005, p. 24.

56 Peces-Barba Martínez, Gregorio, Lecciones de derechos fundamentales, Madrid, Dykinson, 2004, p. 28. 
expressos no texto constitucional. Isto porque a expressão "direitos fundamentais" apresenta uma menor quantidade de ambiguidades que a expressão "direitos humanos". Quando na linguagem jurídica procura se referir aos direitos em suas dimensões atuais muitos se utilizam de termos como “direitos naturais" ou "direitos morais", retirando-se destes direitos sua faceta jurídico-positiva. Mas principalmente porque a designação "direitos fundamentais" integra em seu conceito e conteúdo as duas dimensões essenciais, não reducionistas do jusnaturalismo ou do positivismo, ou seja, a de que dos direitos fundamentais expressam uma moralidade básica e uma juridicidade básica; principalmente pela razão moderna de vinculação de seu reconhecimento jurídico — em nível nacional ou internacional — em um texto de natureza fundamental como a Constituição ou em outro texto positivo legal.

Para Peces-Barba Martínez, quando nos referimos a direitos fundamentais estamos ao mesmo tempo falando de uma pretensão moral justificadora e sua recepção no direito positivo. ${ }^{57}$ Desse modo, para alcançar a compreensão dos direitos fundamentais se deve abarcar ambas as características: a primeira consistente em uma justificação de uma determinada pretensão moral em que consistem tais direitos a partir da ideia da dignidade da pessoa humana como pressuposto para o desenvolvimento integral do ser humano.

Os direitos fundamentais, em nível nacional, e os direitos humanos no campo internacional representam um campo de proteção dos indivíduos sob os quais não é permitido ao Estado ultrapassar. São exatos limites normativos e sociais aos quais inscritos na Constituição e nas leis servem como garantias de aplicação dos direitos e de resguardo em situações de crise. Nesse sentido: "O que vai conferir aos Direitos Humanos essas características de direitos morais é que sua validade suplanta as estrutura jurídica dos Estados Nacionais". ${ }^{58}$ E posteriormente, a consignação deste direito em direito positivado como condição essencial para que se possa eficazmente realizar sua finalidade: os direitos humanos quando integrantes de um determinado sistema normativo segundo as consequências lógicas de vigência e obrigatoriedade no meio social.

57 Ibidem, p. 29.

58 Poker, José Geraldo Alberto Bertoncini et al., "Direitos humanos, linguagem, normatividade e emancipação nas relações internacionais”, en Salatini, Rafael (org.), Cultura e direitos humanos nas relações internacionais. Reflexões sobre os direitos humanos, Marília, Cultura Acadêmica, 2016, p. 37. 
A distinção entre direitos humanos e direitos fundamentais foi elaborada pela doutrina jurídica alemã. Os direitos fundamentais (Grundrechte) seriam os direitos humanos assim reconhecidos pelas autoridades detentoras do poder político de editar normas para regulação unicamente no interior de um Estado; seriam, conseguinte, direitos fundamentais aqueles direitos humanos positivados nas leis, nas Constituições e inclusive reconhecidos no plano internacional pelos tratados e demais documentos de direito supranacionais. ${ }^{59}$

O magistério de Dimitri Dimoulis e Leonardo Martins nos relata a opção pelo termo "direitos fundamentais", em um sentido estritamente jurídico, em preferência a "direitos humanos" ou "direitos naturais" pelo fato de revelarem direitos positivados na Constituição, ao contrário de direitos considerados pré-positivos (naturais) ou supra-positivos (humanos). ${ }^{60}$ Para estes autores os direitos fundamentais são conceituados como “... direitos público-subjetivos de pessoas (física ou jurídicas), contidos em dispositivos constitucionais e, portanto, que encerram caráter normativo supremo dentro do Estado, tendo como finalidade limitar o exercício do poder estatal em face da liberdade individual". ${ }^{61}$

Além do que seria aquele o termo empregado no vocábulo constitucional, pois são aqueles direitos encontrados no texto regulamentador dos fundamentos da organização política e social e ainda, por indicar que nem todos os direitos reconhecidos no sistema jurídico brasileiro são referidos no âmbito do direito constitucional. Seriam, portanto, direitos possuidores de proteção constitucional, logo, uma força jurídica superior às outras normas e por isso constituindo um mínimo de direitos insuscetíveis de abolição quando já previstos ou passíveis de acréscimos segundo a vontade legislativa.

As normas jurídicas nacionais não mencionam a palavra "paz" ou fazem qualquer referência ao direito fundamental à paz na Constituição Federal de 1988 ou demais leis brasileiras. Apenas o artigo 136 da Constituição Federal menciona a possibilidade do presidente da República de decretar estado de defesa para preservar ou prontamente restabelecer, em locais restritos e determinados, a ordem pública ou a "paz social”. Para a Constituição brasileira de 1988, portanto, a paz é a regra do sistema de direitos e garantias. A exceção seria o estado de defesa ou estado constitucional de exceção.

59 Comparato, Fabio Konder, A afirmação histórica dos direitos humanos, 5a. ed., São Paulo, Saraiva, 2007, pp. 58 e 59.

60 Dimoulis, Dimitri e Martins, Leonardo, Teoria geral dos direitos fundamentais, São Paulo, Revista dos Tribunais, 2008, p. 53.

61 Ibidem, p. 54. 
Quando a paz se mostra ameaçada ou afetada entra em vigência a suspensão de específicos direitos individuais e sociais, além de garantias constitucionais: é o sistema constitucional de crises. Em situações em que não há paz alguns direitos fundamentais sofreriam restrições; em situações de normalidade, esses direitos encontram plena efetividade. Na situação de estado de defesa torna-se possível a suspensão dos direitos de reunião, do sigilo da correspondência, e do sigilo das comunicações telefônicas e telegráficas. O controle político desta decretação — de competência exclusiva do presidente da República — é posterior o que significa da sua necessidade de aprovação pelo Congresso Nacional.

Outra situação de exceção em que se define a suspensão da paz em âmbito interno é a decretação do estado de sítio (artigo 137 da Constituição Federal) em caso de declaração de estado de guerra ou em resposta a agressão armada estrangeira. A declaração de guerra ao ocasionar a suspensão do estado de paz social possibilita ainda a aplicação de medidas de exceção: como a pena de morte. Em períodos de paz é vedada a pena de morte no Brasil (artigo 5o., XLVII, “a”) exceto em caso de declaração de guerra. Nessas hipóteses torna-se vigente e aplicável os tipos penais incriminadores do livro II do Código Penal Militar (Decreto-Lei núm. 1.001, de 21/10/1969) cujas penas preveem a morte.

A paz para o ordenamento jurídico brasileiro segue a visão dos pensadores que consideram a paz a ausência de guerra. Logo, não havendo uma situação constitucional de crise em que se faz necessária a declaração de guerra e imposição do estado de defesa (artigo 137 da carta constitucional de 1988), impõem-se a vigência de um estado de paz social.

Poder-se-ia igualmente deduzir de um direito à paz a partir do conjunto normativo de direitos previstos na Constituição Federal. Afinal, em acontecimentos que demandem estado de defesa ou de sítio determinados direitos fundamentais são suspensos. Inclusive o próprio direito à vida. De onde se conclui que somente em tempos de paz é possível o exercício pleno e irrestrito dos direitos e garantias fundamentais insculpidos na Constituição Federal.

Voltando nossos olhos agora para o sistema internacional de direitos e garantias podemos destacar a Declaração de Luarca surgida a partir do I Congresso Internacional pelo Direito Humano à Paz (realizado em San Sebastian, na Espanha) que reconhece o direito humano à paz. Afirma-se na presente declaração (artigo 1o.) que: "As pessoas, os grupos e os povos têm o direito inalienável a uma paz justa, sustentável e duradoura. Em virtude deste direito, são titulares dos direitos enunciados nesta Declaração”. 
Podemos citar ainda outros documentos de vigência internacional que tratam do tema da paz, como a Declaração sobre a Preparação da Sociedade para Viver em Paz, da Organização das Nações Unidas, prevista pela Resolução núm. 33/73, de 15 de dezembro de 1978; Declaração sobre a Prevenção e Solução de Disputas e Situações que possam Ameaçar a Paz e a Segurança Internacionais, Resolução núm. 43/51, de 5 de dezembro de 1988; e, a Declaração sobre o Reforço sobre a Cooperação entre as Nações Unidas e Acordos ou Agências Regionais sobre a Manutenção da Paz e da Segurança Internacionais, Resolução núm. 49/57, de 9 de dezembro de 1994.

A Organização das Nações Unidas definiu ainda uma política internacional de valorização da cultura de paz na Declaração e Programa de Ação sobre uma Cultura de Paz, de 6 de outubro de 1999:

Artigo 1o. Uma Cultura de Paz é um conjunto de valores, atitudes, tradições, comportamentos e estilos de vida baseados: a) No respeito à vida, no fim da violência e na promoção e prática da não-violência por meio da educação, do diálogo e da cooperação; b) No pleno respeito aos princípios de soberania, integridade territorial e independência política dos Estados e de não ingerência nos assuntos que são, essencialmente, de jurisdição interna dos Estados, em conformidade com a Carta das Nações Unidas e o direito internacional; c) No pleno respeito e na promoção de todos os direitos humanos e liberdades fundamentais; d) No compromisso com a solução pacífica dos conflitos; e) Nos esforços para satisfazer as necessidades de desenvolvimento e proteção do meio-ambiente para as gerações presente e futuras; f) No respeito e promoção do direito ao desenvolvimento; g) No respeito e fomento à igualdade de direitos e oportunidades de mulheres e homens; h) No respeito e fomento ao direito de todas as pessoas à liberdade de expressão, opinião e informação; i) $\mathrm{Na}$ adesão aos princípios de liberdade, justiça, democracia, tolerância, solidariedade, cooperação, pluralismo, diversidade cultural, diálogo e entendimento em todos os níveis da sociedade e entre as nações; e animados por uma atmosfera nacional e internacional que favoreça a paz.

Artigo 2o. O progresso até o pleno desenvolvimento de uma Cultura de Paz se conquista através de valores, atitudes, comportamentos e estilos de vida voltados ao fomento da paz entre as pessoas, os grupos e as nações. ${ }^{62}$

62 ONU, Declaração e Programa de Ação sobre uma Cultura de Paz, disponível em: http: / / www.comitepaz.org.br/download / Declara\%C3\%A7\%C3\%A3o\%20e\%20Programa\%20de\%20 A\%C3\%A7\%C3\%A3o\%20sobre\%20uma\%20Cultura\%20de\%20Paz\%20-\%200NU.pdf. 
A Carta da ONU (Organização das Nações Unidas) relata em seu artigo 1o., a paz como meta e como caminho para as relações internacionais quando afirma como propósito daquela organização internacional: Manter a paz e a segurança internacionais e, para esse fim: tomar, coletivamente, medidas efetivas para evitar ameaças à paz e reprimir os atos de agressão ou outra qualquer ruptura da paz e chegar, por meios pacíficos e de conformidade com os princípios da justiça e do direito internacional, a um ajuste ou solução das controvérsias ou situações que possam levar a uma perturbação da paz.

O que nos parece é que é preciso avançar na interpretação atualizada da Carta da ONU, em discussões como a redefinição da composição do Conselho de Segurança, na promoção do desenvolvimento do Direito Constitucional Internacional, o que talvez tenha um impacto mais eficaz na promoção do que temos denominado o direito humano à paz... De maneira que a paz da qual falamos, e à qual atribuímos a característica de direito humano é daquela que se reveste de um caráter mais universal e denso, daquela paz que foge em situações evidentes de conflitos permanentes, persistentes, oriundos de ações estatais ou de atores dedicados a uso da violência como meio ou fim. Um direito típico dentre os denominados de terceira geração. ${ }^{63}$

$\mathrm{O}$ direito à paz a partir do século XX a integrar diversos diplomas normativos internacionais, ainda que não de vinculação obrigatória, mas com características de normas facultativas ou normas diretivas. Embora não se apresente como norma internacional cogente o direito à paz das nações e dos indivíduos se destaca a partir da segunda metade do século passado como uma norma de soft law. Presente em vários textos internacionais desprovidos de caráter jurídico e coercitivo na ordem internacional, mas nem por isso com menos destaque e relevância.

Para o sociólogo português e professor da Universidade de Coimbra, os direitos humanos deveriam ser reconceitualizados como multiculturais. Em sua concepção o multiculturalismo seria “...pré-condição de uma relação equilibrada e mutuamente potenciadora entre a competência global e a legitimidade local, que constituem os dois atributos de uma política contra-

63 Alarcón, Pietro de Jesús Lora, "O direito à paz: a constitucionalização de um direito fundamentalmente humano”, Anais do XVIII Congresso Nacional do CONPEDI, São Paulo, 2009, disponível em: http://www.publicadireito.com.br/conpedi/manaus/arquivos/Anais/sao_paulo/2 518.pdf. 
hegemônica de direitos humanos no nosso tempo". ${ }^{64}$ A partir de uma nova concepção de direitos humanos centrados no aspecto multicultural de sua manifestação poderíamos entender que se referem a eles a sujeitos múltiplos, diferentes entre si embora possam parecer iguais.

O jurista José Afonso da Silva renunciando à perspectiva jusnaturalista acerca dos caracteres dos direitos fundamentais reconhece em um sentido jurídico-positivo sobre eles o caráter de historicidade, inalienabilidade, imprescritibilidade e irrenunciabilidade a estes direitos. ${ }^{65} \mathrm{~A}$ historicidade seria $\mathrm{o}$ atributo de todo direito, pois estes surgiriam em um determinado período e se ampliaram com o passar dos tempos, inclusive se modificando. A imprescretibilidade seria um elemental diferenciador; afinal, em sua maioria os direitos demandam um lapso apto para serem exercidos ou exigidos; logo, enquanto direitos fundamentais, nunca deixam de ser exigíveis.

Inalienabilidade é sua não cessão ou transferência a outrem; embora alguns possam apresentar conteúdo econômico ou patrimonial em regra não se pode alienar um direito fundamental a outra pessoa justamente pelo fato de se imaginar um direito cuja titularidade é inerente a todos. A irrenunciabilidade denota, igualmente, a impossibilidade de renúncia a direitos fundamentais que podem não ser exigidos ou exercidos em um determinado momento e pela circunstância vivenciada, porém, jamais deixam de integrar a esfera de direitos dos indivíduos, pois não há a possibilidade de renúncia a eles.

Por essa razão que podemos compreender que: "A paz, no entanto, a partir da segunda metade do século XX não pode mais ser um desejo, é preciso engastá-la no mesmo conjunto de direitos essenciais à dignidade da vida humana, e torna-la também um direito inalienável”. ${ }^{66} \mathrm{~A}$ paz passa a compor o rol dos direitos fundamentais, ainda que não expressamente positivados no texto constitucional como o estado em que os demais direitos e garantias podem integralmente ser exercidos. Além do que, apresenta a paz todas as demais características inerentes aos direitos fundamentais. Não resta dúvida que “... a paz deixa de ser considerada uma aspiração de cunho meramente moral e passa a ser vista como um verdadeiro direito no marco da afirmação histórica dos direitos humanos". ${ }^{67}$

64 Santos, Boaventura de Souza, "Por uma concepção multicultural de direitos humanos", Revista Crítica de Ciências Sociais, Coimbra, núm. 48, junho de 1997, p. 19.

65 Silva, José Afonso da, Curso de direito constitucional positivo, 29a. ed., São Paulo, Malheiros, 2007, p. 181.

66 Sala, José Blanes, op. cit., p. 131.

67 Alarcón, Pietro de Jesús Lora, op. cit. 
No universo da diplomacia e das relações internacionais a paz diametralmente tem se destacada nos últimos decênios e se tornado o principal objetivo da Organização das Nações Unidas. Somente a paz é capa de manter as conquistas e desenvolvimentos até então alcançados pela civilização com a manutenção da vida, da liberdade, da dignidade e dos demais direitos humanos de conquista histórica. Por essas e outras que o professor de Turim afirma que: "A paz, portanto, almeja, geralmente, conservar um statu quo particularmente satisfatório. A paz é, essencialmente, conservadora”. ${ }^{68}$

Quando Bobbio afirma que se a paz tem função conservadora procura referir que o pacifismo não necessariamente pode ser considerado como uma corrente de pensamento político ligado ao conservadorismo. O pacifismo se localizaria mais ao centro, como uma corrente moderada muito mais próxima do liberalismo do que necessariamente das demais vertentes políticas. A pessoa genuinamente pacifista defende a segurança das relações existentes. Àquela que tem interesse em manter o statu quo, isto é, a mantença das condições que possibilitam o exercício dos demais direitos humanos e fundamentais. Segundo professor alemão Otfried Höffe os direitos fundamentais são os direitos humanos efetivamente reconhecidos por uma ordem jurídica ou constitucional. ${ }^{69}$

Para a existência dos direitos humanos e fundamentais na ordem internacional ou na ordem jurídica interna das nações os direitos antes conquistados devem porventura ser mantidos e protegidos, garantidos e efetivados. O retrocesso social deve ser evitado e repelido, no intuito de conservação dos direitos reconhecidos e positivados juntamente com suas garantias políticas e jurídicas: elementos imprescindíveis para a manutenção da paz.

\section{CONCLUSÕES}

Iniciamos este trabalho apresentando a ideia da organização da sociedade a partir de estruturas normativas e jurídicas emanadas do Estado com a intenção de previsões de agir e não agir. As normas de permissão e as normas

68 Bobbio, Norberto, “Paz e propaganda...”, op. cit., p. 138.

69 Höffe, Otfried, Justiça política, trad. de Ernildo Stein, São Paulo, Martins Fontes, 2001, p. 417. 
proibitivas, criados pelo Estado através do Legislativo servem ao regulamento dos conflitos de convivência entre os integrantes da sociedade. A pessoa jurídica de direito público interna materializa o ente estatal de atuação interna, enquanto a pessoa jurídica de direito publico internacional simboliza a atuação da nação nas relações internacionais.

O objetivo de previsão de normas jurídicas de convivência —mediante o estabelecimento de direitos e deveres - seria o de possibilitar a paz social, ou seja, a diminuição dos conflitos existentes no dia-a-dia da sociedade. Através do Poder Judiciário os conflitos e as lides seriam objetos de julgamento por meio do devido processo legal, autorizando-se assim por meio do Estado-juiz, a aplicação de sanções e a segurança jurídica ao qual seria possível construir uma ideia de paz e de pacificação social. Logo, o Estado pelo Legislativo criaria as leis de aplicação pelo Executivo sob o resguardo do Judiciário em um sistema de freios e contrapesos.

Com a previsão normativa surgem então preceitos permissivos ou impeditivos de determinadas ações; bem como a previsão de mandados criminalizadores. A todos eles teriam o Estado o uso da violência para a consecução de suas ordens e interesses. Todavia, se o conjunto de pessoas vivendo em sociedade representa a legitimação do poder outorgado ao Estado nem sempre a paz social é possível de ser alcançada pelas atuações do próprio governante e de seus representantes.

Para a resolução dos conflitos privados há inúmeras formas de resolução consensuais ou contenciosas. Quando, contudo, as relações de conflito se apresentam entre o Estado e a sociedade por incompatibilidade entre os interesses dos dirigentes governamentais e os indivíduos coletivamente considerados a vontade estatal se prepondera pela atuação da violência. Isso se apresenta desde a conflitos regionalmente localizados até mesmo a grandes confrontos como em iniciativas paramilitares ou em guerras civis. A paz, então, antes como objetivo de resolução de conflitos intersubjetivos passa agora a uma realidade um pouco mais longínqua.

Ainda que essa multiplicidade de confrontos ainda seja uma realidade, o surgimento e a maior incidência e valorização das teorias da paz tiveram um grande avanço no século XX; e, ainda hoje, continuam a despertar interesses doutrinários e acadêmicos. Norberto Bobbio afirma que os problemas fundamentais do nosso tempo são os direitos humanos e os problemas da paz. Assim ainda o são. O pacifismo surge então como uma proposta teórica de estudo e entendimento da paz, seu conceito e formas de exercício. 
Contra as formas de violência e de opressão que afetem direitos humanos - seja no âmbito internacional ou nas realidades domésticas e internas do Estado - e ameaça a existência dos sujeitos que a retomada do tema da paz e as teorias sobre o pacifismo são um alento e uma nova proposta científica.

Neste trabalho a ideia de pacifismo, todavia, não é a de paz interna enquanto um atributo moral. Trabalhamos, sobretudo, com a ideia de paz vinculada a critérios exteriores: não somente como ausência de guerras ou de conflitos entre as nações ou entre o Estado e seus cidadãos. Pois, durante muitos séculos paz foi entendida somente como a ausência de guerra. Defendemos assim à uma nova concepção de direito internacional de paz como uma paz ativa. A paz não seria apenas o resultado do fim de conflitos intestinais ou internacionais, com o término de guerras e a assinatura de declarações de paz.

Durante longo período os teóricos das relações internacionais conceituaram a paz somente como aquele período de tempo e espaço sem guerras. A paz como uma construção política e internacional de existência independente da guerra ganha maior força e destaque com as pesquisas sobre a paz (peace research). A polemologia ou pesquisas para a paz, em sua unanimidade, passam a considerar a violência como um mal a ser evitado para ao alcance da paz. Quando constatado internacionalmente que os conflitos - guerras quentes ou frias - podem levar ao risco da destruição atômica global e do morticínio de milhões de pessoas, a paz surge como resposta.

O pensamento pacifista — do século XVI ao século XIX — basicamente se circunscreveu a três correntes de pensamentos: teoria do irenismo cristão, a paz em conceitos religiosos; teoria da cidade pacífica, em que uma sociedade perfeita não deve encontrar razões para o uso da guerra; e, teoria do federalismo internacional com as ideias de paz perpétua, sobretudo em Saint-Pierre e em Kant.

O conceito de paz está intimamente ligado ao conceito de guerra. Por essa razão que a paz, durante grande parte do pensamento político internacional, têm se sustentado enquanto uma definição negativa: enquanto ausência de guerra. Contudo, embora muitos acreditem que a história do mundo é inexoravelmente a das guerras o pensamento pacifista surge com uma nova proposta: a paz ativa. O caminho para se alcançar a paz deve ser somente através da própria paz.

$\mathrm{Na}$ valorização ainda da guerra no cenário do mundo o direito internacional e os escritos de ciência política, quando tratam do tema da guerra, utilizam as expressões jus ad bellum (direito da guerra) e jus in bello (direito 
na guerra) como argumentos a delimitar a possibilidade de retaliação bélica contra um ataque ou do uso da força e contra quem serão utilizadas. Pois, em conflitos bélicos tendem a restringir os direitos humanos e ser exceções a toda construção histórica de garantias e de existência. A guerra não ataca somente o inimigo e sim também civis e uma infinidade de pessoas alheias ou não causadoras daquele conflito.

A justificar a guerra muitos teóricos afirmam ser esta apenas a consequência de causas anteriores. Tão somente um meio além diplomático de uso da força. A guerra passa a ser considerada com justa, necessária, ideal; a fomentar o desenvolvimento econômico, tecnológico e científico das nações. Então, seria a humanidade beneficiada por isso. O objetivo de propor o pacifismo como alternativa à guerra é justamente o de encontrar outros caminhos para a construção da realidade da paz sem o contributo da guerra.

A paz, portanto, é o caminho presente e futuro —em nível nacional ou na relação entre os Estados soberanos — para a convivência entre as pessoas. A guerra — seja ela justa ou injusta — causa sofrimento, morte, destruição, prejuízos irreparáveis. Se o conflito é inerente à própria existência humana e da dinâmica da convivência social, não sendo possível sua eliminação total, como melhor saída seria as propostas que se utilizam do caminho e tenham como resultado a paz.

A paz como um elemento de direito humano e fundamental, imperativo e imprescindível, à toda existência com dignidade — atendendo ao comando constitucional — bem como um pré-requisito para o exercício dos demais direitos individuais, sociais e coletivos. Para alcançar a compreensão dos direitos fundamentais se deve ter em mente uma justificação de uma determinada pretensão moral em que consistem tais direitos a partir da ideia da dignidade da pessoa humana como pressuposto para o desenvolvimento integral do ser humano. Os direitos fundamentais, em nível nacional, e os direitos humanos no campo internacional representam um limite de proteção dos indivíduos sob os quais não é permitido ao Estado ultrapassar, pois, a validade desses direitos ultrapassa a própria estrutura jurídica dos Estados nacionais.

Na Constituição da República Federativa do Brasil de 1988 a palavra "paz" tem relação direta com uma situação de normalidade política, jurídica e social ameaçável somente quando dos estados de exceção e de conflitos: decretação de estado de defesa e estado de sítio. Nestas situações, de ausência de paz, haveria a suspensão de determinados direitos fundamentais e suas garantias constitucionais. O conceito de paz para o ordenamento jurídico 
brasileiro é o mesmo conceito clássico do direito internacional: a ausência de guerras.

No âmbito das relações internacionais e das normas supranacionais, contudo, a construção de uma ideia de paz se encontra mais avançada. A paz se apresenta como um direito humano previstos em diversas declarações e cartas de direitos. Um direito humano inalienável, irrenunciável e de construção histórica. Embora sem caráter cogente ou coativo o direito humano à paz, nas relações entre nações, ganha destaque como uma norma de soft law. A paz, então, consiste em um direito humano fundamental.

O pacifismo então representa um conjunto de ideias, pensamentos, fundamentações, doutrinas e atitudes que rejeitam o uso da guerra e entendem a paz como uma construção possível e realizável, internamente ou internacionalmente. O pacifismo no século XX ganha maior destaque e curiosidade acadêmica e científica como um movimento de reivindicação de direitos e formas de exercício de inconformidade, protestos e enfrentamentos sociais organizados, todavia, com um elemento que o diferencia dos demais e dos séculos pretéritos que é a rejeição da violência com a ideia de práticas nãoviolentas. O pacifismo seria então uma filosofia política da não-violência. Não um pacifismo passivou ou natural como consequência do desenvolvimento histórico da humanidade. Ao contrário, como uma teoria e doutrina de ação. A proposta de um pacifismo ativo, ou seja, a paz como um esforço racional e pretendido nas ações da sociedade.

O pacifismo ativo, portanto, é aquele que melhor se harmoniza com o entendimento do pacifismo como uma doutrina política de organização, reivindicação e garantia de direitos humanos e fundamentais juntamente com a negação da guerra e da violência e por medidas não-violentas. $\mathrm{O}$ pacifismo ativo como idealizado por Bobbio e debatido por Rafael Salatini pode ser de forma instrumental, institucional ou finalístico. Raymond Aron, no entanto, classifica a paz como potência, impotência e a paz satisfação. Bobbio ainda cita outras classificações como o pacifismo iluminista, o pacifismo positivista e o pacifismo socialista.

O pensamento pacifista no século XX como um objetivo a ser alcançado por todas as nações e em todas as nações se fundamenta, sobretudo, no pressuposto da paz como concepção política, isto é, em que a paz seria o resultado de um acordo político entre governantes e buscado como objetivos do direito internacional e como garantia do ordenamento jurídico interno do Estado-nação. 


\section{BIBLIOGRAFIA}

Alarcón, Pietro de Jesús Lora, “O direito à paz: a constitucionalização de um direito fundamentalmente humano", Anais do XVIII Congresso Nacional do CONPEDI, São Paulo, 2009, disponível em: http: / / www.publicadireito. com.br/conpedi / manaus/arquivos/Anais/sao_paulo/2518.pdf.

Aron, Raymond, Paz e guerra entre as nações, 2a. ed., trad. de Sergio Bath, Brasília, Universidade de Brasília, 1986.

BobBio, Norberto, A era dos direitos, trad. de Carlos Nelson Coutinho, São Paulo, Elsevier, 2004.

BовBIO, Norberto, "Paz e propaganda de paz", Brazilian Journal of International Relations, Marília, vol. 4, núm. 1, janeiro-abril de 2015.

BobBio, Norberto, Teoria da norma jurídica, 4a. ed., trad. de Fernando Pavan Baptista e Ariani Bueno Sudatti, Bauru, Edipro, 2008.

BoBbIO, Norberto, Teoria geral da política: a filosofia política e a lição dos clássicos, trad. de Daniela Beccaccia Versiani, Rio de Janeiro, Campus Editora, 2000 .

BoBBITT, Philip, A guerra e a paz na história moderna. O impacto dos grandes conflitos e da política na formação das nações, trad. de Cristiana de Assis Serra, São Paulo, Campus, 2003.

BonanATE, Luigi, A guerra, trad. de Maria Tereza Buonafina e Afonso Teixeira Filho, São Paulo, Estação Liberdade, 2001.

Bouthoul, Gaston, Viver em paz, trad. de Antonio José Massano, São Paulo, Moraes Editores, 1968.

Clausewitz, Carl von, Da guerra, trad. de Maria Teresa Ramos, São Paulo, Martins Fontes, 1996.

COMPARATO, Fabio Konder, A afirmação histórica dos direitos humanos, 5a. ed., São Paulo, Saraiva, 2007.

CusA, Nicolau de, A paz da fé, trad. de João Maria André, Coimbra, Minerva Coimbra, 2002.

DíAZ I ANABITARTE, Aitor, "Hacia una sistematización del pacifismo político", Revista Española de Ciencia Política, Madrid, núm. 31, 2013.

Dimoulis, Dimitri e MARTINS, Leonardo, Teoria geral dos direitos fundamentais, São Paulo, Revista dos Tribunais, 2008. 
FOTIA, Mauro, "Polemologia, psicanálise e ciência política”, Revista de Ciência Política, Rio de Janeiro, vol. 2, setembro-dezembro de 1980.

GentiLI, Alberico, O direito de guerra, trad. de Ciro Mioranza, Ijuí, Unijuí, 2006.

Grotius, Hugo, O direito da guerra e da paz, 2a. ed., trad. de Ciro Mioranza, Ijuí, Unijuí, 2005, vol. I.

HÖFFE, Otfried, Justiça política, trad. de Ernildo Stein, São Paulo, Martins Fontes, 2001.

Honneth, Axel, Luta por reconhecimento. A gramática moral dos conflitos sociais, 2a. ed., trad. de Luiz Repa, São Paulo, Editora 34, 2009.

KeEGAN, John, Uma história da guerra, trad. de Pedro Maia Soares, São Paulo, Companhia das Letras, 1998.

LEÃo JúniOR, Teófilo Marcelo de Ârea e JuLiAs, Lívia Pacheco de Freitas, "A Corte Suprema e o seu papel atual perante a sociedade, judicialização e ativismo judicial adequados", Revista do Instituto de Direito Constitucional e Cidadania, Londrina, vol. 4, núm. 2, dezembro de 2019.

MATIJASCIC, Vanessa Braga, "Pesquisas para a paz e o ativismo da cultura da paz”, en SALATINi, Rafael e DiAS, Laércio Fidelis (orgs.), Reflexões sobre a paz, vol. II: Paz e tolerância, São Paulo, Cultura Acadêmica, 2018.

Mazzuoli, Valerio de Oliveira, Curso de direito internacional público, 9a. ed., São Paulo, Revista dos Tribunais, 2015.

MEI, Eduardo, "Estado, guerra e violência: as novas guerras e suas implicações para a teoria clausewitziana da guerra”, en MEI, Eduardo e SAINTPIERRE, Héctor Luis (orgs.), Paz e guerra. Defesa e segurança entre as nações, São Paulo, Editora Unesp, 2013.

MORRIS, Ian, Guerra. O horror da guerra e seu legado para a humanidade, trad. de Luis Reyes Gil, São Paulo, LeYa, 2015.

PECES-BARBA MARTíneZ, Gregorio, Lecciones de derechos fundamentales, Madrid, Dykinson, 2004.

PÉREZ Luño, Antonio Henrique, Derechos humanos, Estado de derecho y Constitución, 9a. ed., Madrid, Tecnos, 2005.

POKER, José Geraldo Alberto Bertoncini, "Direitos culturais, universalismo e movimentos sociais: o futuro dos direitos humanos", en SALATINI, Rafael (org.), Reflexões sobre a paz, vol. II: Paz e tolerância, Marília, Cultura Acadêmica, 2018.

POKER, José Geraldo Alberto Bertoncini et al., "Direitos humanos, linguagem, normatividade e emancipação nas relações internacionais", en SA- 
LATINI, Rafael (org.), Cultura e direitos humanos nas relações internacionais. Reflexões sobre os direitos humanos, Marília, Cultura Acadêmica, 2016.

PONTARA, Giuliano, "Pesquisa científica sobre a paz", en BOBBIO, Norberto et al., Dicionário de política, Brasília, UnB, 1992, vol. 2.

REZEK, Francisco, Direito internacional público. Curso elementar, 15a. ed., São Paulo, Saraiva, 2014.

SAINT-PIERRE, Abbé de, Projeto para tornar a paz perpétua na Europa, trad. de Sergio Duarte, Brasília, Editora UnB, 2003.

SALA, José Blanes, "A contribuição histórica do direito internacional público para a consecução da paz”, en SALATINI, Rafael (org.), Reflexões sobre a paz, Marília, Cultura Acadêmica, 2014.

SAlatini, Rafael, "Bobbio, a paz e os direitos do homem", Revista Direito GV SP, janeiro-junho de 2011.

SALATINI, Rafael, "Introdução aos escritos sobre a paz de Norberto Bobbio", Revista Videre, Dourados, vol. 10, núm. 18, 2017.

SAlATINI, Rafael, "O tema da paz no século XX”, en PASSOS, Rodrigo Duarte Fernandes dos e FuCCILlE, Alexandre (orgs.), Visões do Sul. Crise e transformações do sistema internacional, Marília, Cultura Acadêmica, 2016, vol. 1.

SALATINI, Rafael, "O tema da paz perpétua”, Brazilian Journal of International Relations, Marília, vol. 2, núm. 1, janeiro-abril de 2013.

SALATINI, Rafael, "Rousseau e as relações internacionais", Pacifismo e cooperação nas relações internacionais: teoria e prática, Dourados, UFGD Editora, 2013.

SANTOS, Boaventura de Souza, "Por uma concepção multicultural de direitos humanos", Revista Crítica de Ciências Sociais, Coimbra, núm. 48, junho de 1997.

SILVA, José Afonso da, Curso de direito constitucional positivo, 29a. ed., São Paulo, Malheiros, 2007.

WolkMER, Antônio Carlos, Introdução ao pensamento jurídico crítico, 7a. ed., São Paulo, Saraiva, 2009.

Zolo, Danilo, "Luzes e sombras do pacifismo jurídico de Norberto Bobbio", en Tosi, Giuseppe (org.), Norberto Bobbio: democracia, direitos humanos, guerra e paz, João Pessoa, Editora da UFPB, 2013. 